\title{
OBITUARY
}

\section{Rev. W. Hopkyn Rees, D.D.}

William Hopkyn Rees began his qualifications for language study and teaching by being born at Cwmavon in the Welsh speaking part of Wales. As quite a young man he decided on the ministry. Theological training in Bala and a short pastorate in Wales prepared him to go out to China under the London Mis onary Society. He sailed with his wife, in the autumn of 1883, for China, travelling out on the same boat as James Gilmour of Mongolia. After learning the language in Peking, he went out into the middle of the great plain of Chihli, some 200 miles south of Peking, there to found the station near Chichou which ultimately came to be called Siaochang. The station was in the midst of the territcry swept by the Boxer rising, but fortunately Hopkyn Rees had left for furlough in England a short time before.

Returning in 1901, he rendered such help to the Chinese authorities in the settlement of indemnity claims that he received the order. of the "Blue Button". By this time he had established his reputation, not only as a man who knew the windings of Chinese life in their every turn, but as a Chinese scholar. He had an unusual memory for the character. It was natural, therefore, that when he was appointed to the Union Theological College in Peking, he should at the same time join in founding the Language School in Peking for missionaries and other Europeans. The magnitude to which that school has grown is some measure of the competence of its founders. He was chosen one of the board of revisers for the Mandarin Old Testament. The last stage of his work in China began in 1913, when he was appointed to the staff of the Christian Literature Society in Shanghai. In 1916 he became General Secretary, and he only resigned in 1921 because illhealth compelled it. He was responsible for the editing and translation of many books, but his greatest work was the translation of the old Testament articles of Hastings' One Volume Bible Dictionary, while Dr. McGillivray took the New Testament. It was not possible to translate directly, many of the ideas of criticism had to be re-expressed if they were to have any relation to the stage of Biblical scholarship which the Chinese Christians in the mass had then reached, and only those who have attempted such a piece of work can realize the enormous labour which it cost. It was so successful that before publication the 
first edition of 5,000 was sold out. On his resignation in 1921 he was appointed to the School of Oriental Languages in London, and of his work there someone at the school can speak. But two final and most fitting honours came to him just before he died. First the Chairmanship of the Union of Welsh Independents, and second that of the Board of the London Missionary Society. In neither case was he able to take his place as Chairman, but the honours themselves were conferred with such spontaneous appreciation that the occupancy of either chair was needless.

In all the work that he did Mrs. Rees played her part. She had a special power of understanding the Chinese mind, and in district work, above all, the two co-operated almost as one. Four of the seven children have been missionaries or the wives of missionaries.

Dr. Rees enjoyed a remarkable popularity wherever he was known, but above all in Wales. His knowledge of China and his human interest in handling what he knew in the most sympathetic way made him an unusually good speaker, and he did a great work in making large audiences understand a little more of the conditions in the Far East. As is suggested by the bare record of his appointments, he lived a life full of activity, and if the reward of longer years had been offered to him at the price of going slow, he would certainly have refused it. He was one of the most comradely and eager of friends. He gave his best in friendship without stint or reserve. He was first and foremost a Christian, and, because his religion was a complete and all round thing, he gave the impression that it was second nature. As compared with the lives many men live to-day, his period of 65 years was not long, but few men, even in a long life, have had so much of joy in realizing the best of their ambitions. In his illness over and again he gave thanks for the mercy and gladness which had marked all his career. That was characteristic of his buoyancy and courage. "Whom the gods love, die young" was pre-eminently true of Hopkyn Rees.

To this appreciation by an old friend, I wish to add a few words frcm one who only had the privilege of Dr. Hopkyn Rees's acquaintance during the short period he was able to serve as Reader in Chinese in our School. Dr. Rees was no longer a young man when he came to us, in 1920 , but he at once entered into his duties with a keenness and vigour of which a far younger man might well be proud. For Dr. Rees all students alike were the object of his solicitous care, and the same 
trouble was bestowed on the beginner as on the advanced student. His direct and practical method of instruction, coupled with his rare knowledge of spoken Mandarin, resulted in consistent and rapid progress, and his name will be gratefully remembered by numbers of students who passed through his hands in these four years. But the loss we feel here is not merely the loss of a great teacher, but in equal measure the loss of a personality which had gained the affection and respect of all his colleagues.

Editor. 